\title{
Papillary cystadenocarcinoma of the sublingual gland: case report and literature review
}

\author{
Polytimi P. Paschalidi', Nikolaos G. Nikitakis², Dimosthenis Igoumenakis ${ }^{3}$, George Kostakis ${ }^{1}$ \\ ${ }^{1}$ Department of Oral and Maxillofacial Surgery, School of Dentistry, National and Kapodistrian University of Athens, 11527 Athens, Greece. \\ ${ }^{2}$ Department of Oral Medicine and Pathology, School of Dentistry, National and Kapodistrian University of Athens, 11527 Athens, Greece. \\ ${ }^{3}$ Department of Oral and Maxillofacial Surgery, "Venizeleio" General Hospital of Heraklion, 71409 Heraklion, Greece.
}

Correspondence to: Dr. Polytimi P. Paschalidi, Department of Oral and Maxillofacial Surgery, School of Dentistry, National and Kapodistrian University of Athens, 11527 Athens, Greece. E-mail: polina_paschal@hotmail.com

How to cite this article: Paschalidi PP, Nikitakis NG, Igoumenakis D, Kostakis G. Papillary cystadenocarcinoma of the sublingual gland: case report and literature review. Stomatological Dis Sci 2017;1:81-6.

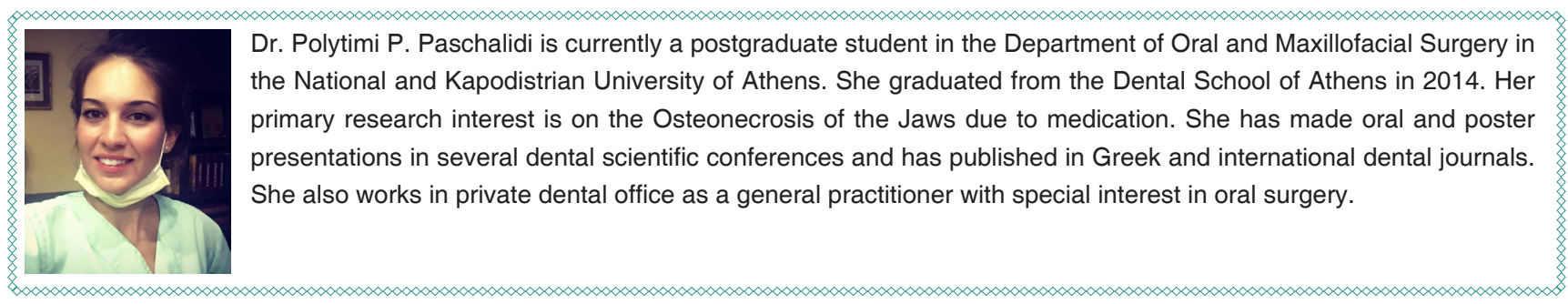

Article history:

Received: 24-12-2016

Accepted: 13-02-2017

Published: 29-06-2017

Key words:

Papillary cystadenocarcinoma,

sublingual gland,

cystic structures

\begin{abstract}
Papillary cystadenocarcinoma (CAC) a rare malignant salivary gland tumor which commonly arises in the major glands, mainly the parotid, and less frequently in the minor salivary glands. Localization in the sublingual salivary gland is very rare. The authors present a case of papillary CAC originating from the right sublingual gland in a 78-year-old female. A review of the literature revealed only 3 previously published detailed cases (in addition to 2 cases as part of larger series) of papillary CAC of the sublingual gland. The salient demographic, clinical, and histopathologic findings of papillary CAC, as well as its surgical treatment, are discussed.
\end{abstract}

\section{INTRODUCTION}

Tumors arising in the sublingual salivary glands are rare and in their vast majority, malignant. ${ }^{[1]}$ Papillary cystadenocarcinoma (CAC) is a rare malignant salivary gland neoplasm with low-grade histologic and clinical features, which was first defined by World Health Organization (WHO) in 1991. ${ }^{[2]}$ Until then, it was classified as an atypical form of adenocarcinoma, also called malignant papillary cystadenoma, low-

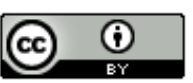

This is an open access article licensed under the terms of Creative Commons Attribution 4.0 International License (https://creativecommons.org/licenses/by/4.0/), which permits unrestricted use, distribution, and reproduction in any medium, as long as the original author is credited and the new creations are licensed under the identical terms.

For reprints contact: service@oaepublish.com

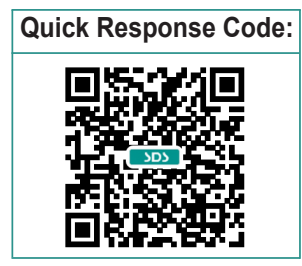


grade papillary adenocarcinoma, or mucus-producing adenopapillary carcinoma. ${ }^{[3]}$ This tumor most commonly arises in the major salivary glands, primarily in the parotid. Involvement of the minor salivary glands, as well as intraosseous localization, have rarely been reported. ${ }^{[3]}$ CAC seems to affect the sublingual gland in a greater proportion of cases compared to other benign or malignant tumors. ${ }^{[3-5]}$ Interestingly, a similar histologic type of tumor can also occur in the ovary, bladder, bile duct, pancreas, mammary gland, thyroid, and upper respiratory tract. ${ }^{[6]}$

In 1996, Foss et al. ${ }^{[4]}$ reported the largest series of salivary gland CAC according to the files of the Armed Forces Institute of Pathology. There was no gender predilection, while the average patients' age was 59 years with $70 \%$ of patients being over 50 . Among these tumors, $65 \%$ were located in the major glands and $35 \%$ in the minor glands (including the lips, buccal mucosa, palate, tongue, retromolar area, and floor of mouth). In this study, only 2 cases arose in the sublingual gland. ${ }^{[4]}$

In the present article, an exceedingly rare case of papillary CAC of the right sublingual gland in a 78-yearold patient is presented, along with a review of the pertinent English-language literature.

\section{CASE REPORT}

A 78-year-old female patient was referred to an oral and maxillofacial surgery clinic by her general practitioner, due to a swelling in the floor of the mouth. The patient stated that the swelling had appeared about 3 months earlier and had exhibited progressive growth, being otherwise asymptomatic. Her medical history was positive for Parkinson's disease, managed with levodopa. She was a non-smoker. Her clinical examination revealed an approximately $3 \mathrm{~cm} \times 2 \mathrm{~cm}$ non-tender tumor, covered by normal mucosa with a smooth surface, occupying the right floor of the mouth [Figure 1A]. On palpation, the tumor had an elastic consistency and was mobile. The outflow of saliva from the Wharton's duct was normal. No neuropathy was identified, and the rest of her clinical examination of the head and neck was unremarkable. A computed tomography (CT) scan of the head and neck depicted a $3.1 \mathrm{~cm} \times 2.0 \mathrm{~cm} \times 2.7 \mathrm{~cm}$ homogeneous lesion with well-defined borders was located in the right sublingual space. There was no erosion of the adjacent lingual plate of the mandible [Figure 1B]. The differential diagnosis included salivary gland pathologic entities, including benign neoplasms (e.g. pleomorphic adenoma), malignant neoplasms (e.g. mucoepidermoid carcinoma, and adenoid cystic carcinoma), and inflammatory lesions (such as chronic sialadenitis).

A fine needle aspiration cytology did not render conclusive results. Thus, the lesion was further investigated with incisional biopsy under local anesthesia. The histopathologic examination revealed numerous haphazardly arranged cystic spaces of variable size, with papillary projections within the cystic lumen. The cystic lining was composed of columnar and mucous cells. Focal areas suggestive of local infiltrative growth into the adjacent connective tissue and salivary gland elements were noticed [Figure 2]. Overall, these features were considered indicative of a cystic salivary gland neoplasm suggestive of CAC, although the possibility of cystadenoma could not be totally excluded. Complete removal of the lesion was recommended.

Surgical excision of the tumor was undertaken under general anesthesia. Intraoperatively, a nonencapsulated tumor, which was adhered to the submandibular duct and to the mylohyoid muscle was found. Notably, the latter appeared to be atrophic, possibly due to pressure by the enlarging tumor. No sign of gross invasion of the adjacent tissues was identified. The duct was preserved, as it was dissected off the tumor and resutured on the mucosa of the floor of the mouth.

Macroscopic examination of the surgical specimen revealed a partially circumscribed tan-brown multilobular and multicystic tumor measuring $3.5 \mathrm{~cm}$ $\times 3.0 \mathrm{~cm} \times 1.8 \mathrm{~cm}$. Histological examination showed numerous cystic structures partially filled with mucin and separated by connective tissue. The cystic lining consisted of epithelial cells varying from large cuboidal to tall columnar, with occasional admixed mucous cells, and showing mild nuclear pleomorphism and infrequent mitotic figures. The epithelium lining formed papillary projections within the cystic lumina. Focal areas of infiltrative growth of the cystic elements into
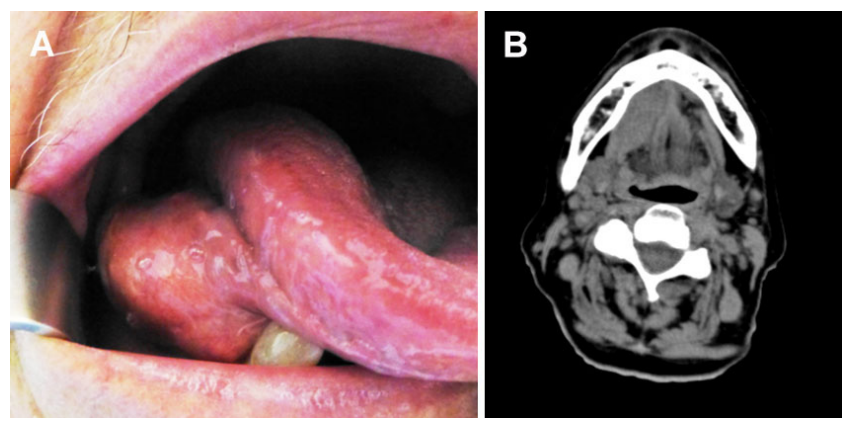

Figure 1: (A) A sublingual mass of elastic consistency covered by normal mucosa located in the right floor of the mouth extending towards the ventral surface of tongue; (B) computed tomography scan (axial view) showing a homogeneous oval-shaped lesion with well defined borders in the right sublingual space 
the surrounding connective tissue and salivary gland parenchyma were observed [Figure 3]. The tumor cells focally approximated but did not extend to the margins of the resection. A final diagnosis of papillary CAC arising from the sublingual gland was rendered.

Considering the patient's age and the fact that CAC is a low-grade malignancy, no adjunctive therapy was
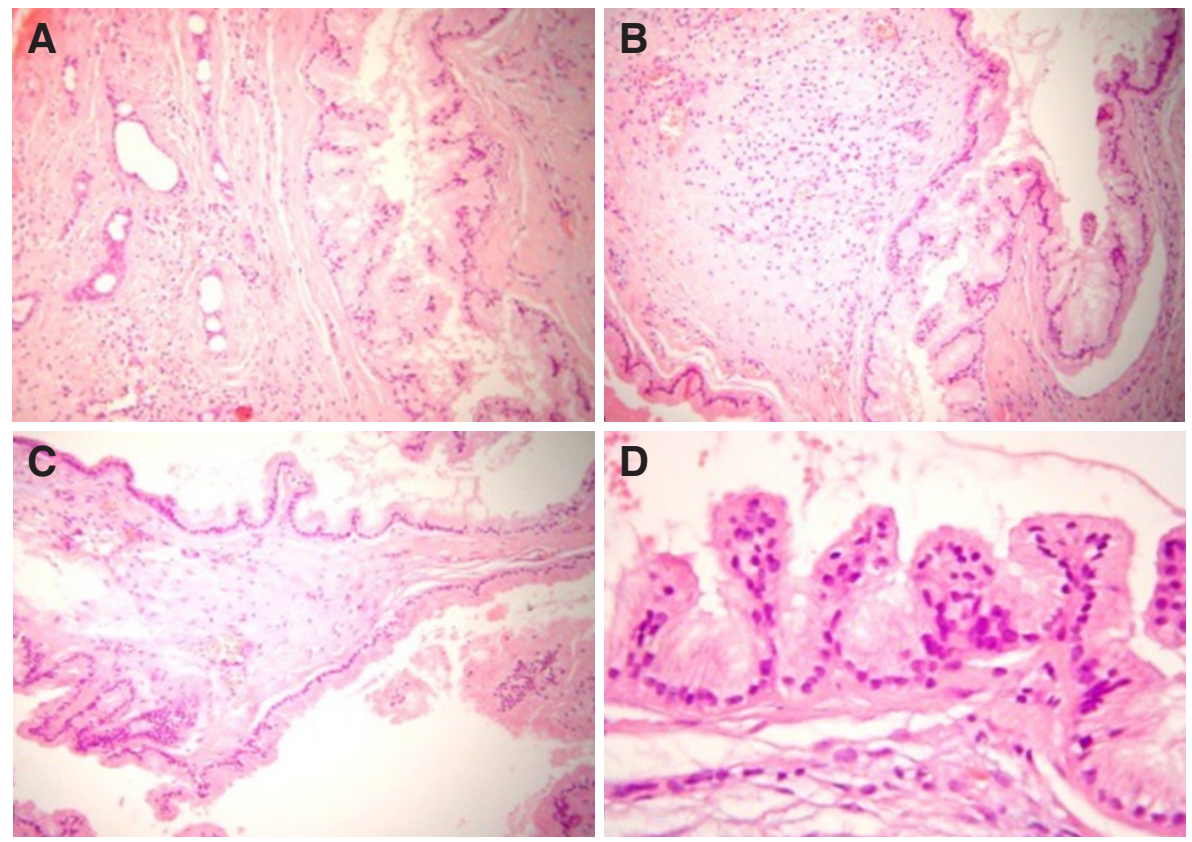

Figure 2: Histologic examination of the biopsy specimen. (A-C) Numerous haphazardly arranged cystic spaces of variable size, with papillary projections within the cystic lumen. Focal areas suggestive of local infiltrative growth into the adjacent connective tissue and salivary gland elements were noticed; (D) the cystic lining is composed of columnar and mucous cells. HE stain, $\times 200$ in A-C and $\times 400$ in D
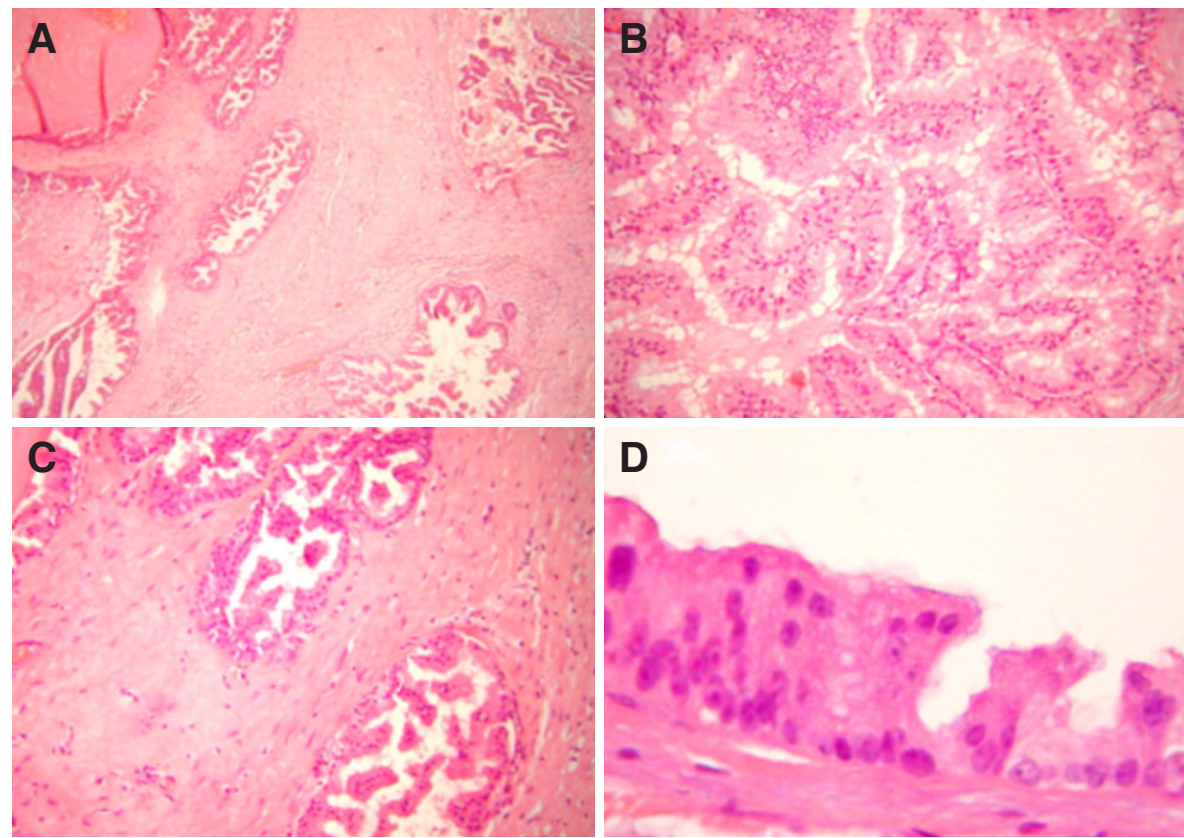

Figure 3: Histologic examination of the surgical specimen. (A-C) Numerous cystic structures with papillary projections showing an infiltrative growth pattern within the connective tissue stroma. The epithelial lining forms papillary projections within the cystic lumina; (D) the cystic lining consists of epithelial cells varying from large cuboidal to tall columnar, with admixed mucous cells, showing only mild nuclear pleomorphism. HE stain, $\times 200$ in A-C and $\times 400$ in D 
Table 1: Previously published cases of papillary cystadenocarcinoma of the sublingual gland

\begin{tabular}{|c|c|c|c|c|c|c|c|c|}
\hline & $\begin{array}{l}\text { Age, } \\
\text { years }\end{array}$ & Gender & Duration & Clinical features & Imaging & Histologic features & Treatment & Follow-up \\
\hline $\begin{array}{l}\text { Danford et al., }{ }^{[9]} \\
1992\end{array}$ & 38 & Male & 2 weeks & $\begin{array}{l}\text { Painless, bulky, } \\
\text { lobulated, cyst-like } \\
\text { swelling in the floor of } \\
\text { the mouth }\end{array}$ & - & $\begin{array}{l}\text { Low grade (cystic tumor } \\
\text { lined by columnar epithelium } \\
\text { with papillary processes) }\end{array}$ & $\begin{array}{l}\text { 1st: excision; } \\
\text { 2nd: wide excision of } \\
\text { the floor of the mouth } \\
\text { and the right side } \\
\text { of the tongue with } \\
\text { supraomohyoid neck } \\
\text { dissection }\end{array}$ & $\begin{array}{l}\text { At } 6 \text { months: } \\
\text { free of disease }\end{array}$ \\
\hline $\begin{array}{l}\text { Kobayashi et al., } \\
1999\end{array}$ & 55 & Male & - & $\begin{array}{l}\text { Tender, ulcerated } \\
\text { spherical tumor mass } \\
\text { in the floor of the } \\
\text { mouth }\end{array}$ & $\begin{array}{l}\text { MRI: highly intensive } \\
\text { mass surrounded by } \\
\text { low intensity areas } \\
\text { - several enlarged } \\
\text { cervical lymph nodes }\end{array}$ & $\begin{array}{l}\text { Low grade* (cystic cavities } \\
\text { with papillary projections, } \\
\text { columnar and cuboidal cells, } \\
\text { occasional mitotic figures, } \\
\text { lymphatic invasion) }\end{array}$ & $\begin{array}{l}\text { Resection and } \\
\text { ipsilateral supra-hyoid } \\
\text { neck dissection }\end{array}$ & $\begin{array}{l}\text { At } 1 \text { year: free } \\
\text { of disease }\end{array}$ \\
\hline $\begin{array}{l}\text { Yamada et al.., } \\
2007\end{array}$ & 67 & Male & 10 years & $\begin{array}{l}3.0 \mathrm{~cm} \times 2.5 \mathrm{~cm} \times \\
0.3 \mathrm{~cm} \text {, well-defined, } \\
\text { elastic hard and tender } \\
\text { mass in the floor of } \\
\text { the mouth and the } \\
\text { submandibular region }\end{array}$ & $\begin{array}{l}\mathrm{CT}: 3.0 \mathrm{~cm} \times 1.5 \mathrm{~cm} \text {, } \\
\text { slightly enhanced } \\
\text { homogeneous oval- } \\
\text { shaped mass with } \\
\text { relatively clear } \\
\text { margins }\end{array}$ & $\begin{array}{l}\text { High grade (columnar cells, } \\
\text { high cellularity and mitotic } \\
\text { activity, 14-18 mf/10 hpf) }\end{array}$ & $\begin{array}{l}\text { 1st: enucleation; } \\
\text { 2nd: } \\
\text { mandibularresection, } \\
\text { neck dissection and } \\
\text { chemotherapy }\end{array}$ & $\begin{array}{l}\text { At } 3 \text { months: } \\
\text { recurrence and } \\
\text { cervical LNM; } \\
\text { at } 18 \text { months: } \\
\text { alive with } \\
\text { disease }\end{array}$ \\
\hline Present case & 78 & Female & 3 months & $\begin{array}{l}\text { Non-tender tumor in } \\
\text { floor of the mouth with } \\
\text { smooth surface and } \\
\text { elastic consistency }\end{array}$ & $\begin{array}{l}\mathrm{CT}: 3.1 \mathrm{~cm} \times \\
2.0 \mathrm{~cm} \times 2.7 \mathrm{~cm} \\
\text { homogeneous lesion } \\
\text { with well defined } \\
\text { borders }\end{array}$ & $\begin{array}{l}\text { Low grade (numerous cystic } \\
\text { structures with papillary } \\
\text { projections, large cuboidal } \\
\text { to tall columnar cells, } \\
\text { infrequent mitotic figures) }\end{array}$ & Surgical excision & $\begin{array}{l}\text { At } 18 \text { months: } \\
\text { free of disease }\end{array}$ \\
\hline
\end{tabular}

Only cases with sufficient information are included in this table. Two additional cases of papillary cystadenocarcinoma of the sublingual gland (without specific details) were included in the series of Foss et al. ${ }^{[4]}$ *The authors argue that the predominance of columnar cells and the presence of lymphatic invasion suggest an aggressive potential. MRI: magnetic resonance imaging; CT: computed tomography; mf: mitotic figures; hpf: high-power field; LNM: lymph node metastasis

may arise from the sublingual gland, the submandibular duct or adjacent minor salivary glands. Therefore, the differential diagnosis of a tumor in the sublingual gland area includes various salivary gland pathologic entities, such as benign and malignant neoplasms, and nonneoplastic entities (e.g. sialolithiasis, salivary gland cysts, and inflammatory conditions-sialadenitis). ${ }^{[8]}$ For example, cases of sublingual gland tumors mimicking a ranula have been reported. ${ }^{[9]}$ Imaging techniques, such ultrasound, CT and magnetic resonance imaging, may provide valuable information regarding the origin of a tumor in the sublingual area. ${ }^{[10]}$ Determination of the exact site of development as well as definitive diagnosis relies upon surgical removal and histopathologic examination. ${ }^{[8]}$

When a growing sublingual gland tumor exerts pressure on the Wharton's duct, obstructive phenomena of the submandibular gland, manifested as swelling and/or sialadenitis may additionally develop. ${ }^{[11]}$ Furthermore, pain and neuropathy may occur, especially in association with late stage malignant tumors. ${ }^{[12]}$ In the present case, the tumor had obtained a significant size and was adhered to the duct. Surprisingly though, the patient had experienced only minor symptoms, and the outflow of saliva had remained normal. It has been suggested that, due to frequent absence of symptoms, most sublingual gland tumors are diagnosed at later stages. ${ }^{\left[{ }^{[8]}\right.}$ Tumors of the sublingual glands are very often malignant, the percentage of malignancies estimated as $84-87 \%$ in various large series. ${ }^{[12,13]}$ The most common malignant histologic types of the sublingual gland are adenoid cystic and mucoepidermoid carcinoma (the former accounting for $64-84 \%$ of all malignancies). ${ }^{[7,12,14]}$ In contrast, reports about CACs of the sublingual glands are exceedingly rare. ${ }^{[3]}$

A review of the literature revealed only 3 single case reports of sublingual gland CAC, as well as 2 additional cases included in the series of Foss et al. ${ }^{[4,6,9,15]}$ [Table 1] In general, salivary gland CACs are uncommon representing only a small minority of all salivary gland tumors. ${ }^{[3]}$ Unlike salivary glands, CACs are relatively frequent in other organs, such as the mammary gland, the bile ducts, the pancreas and the ovaries. ${ }^{[12]}$

In the 5 previously published cases of sublingual gland CAC, 3 affected males with a mean age of 53.3 years, while age and sex were not specified for the other 2 cases [Table 1]. Thus, the case presented here is the first published example of sublingual gland CAC to affect a female; in addition, our patient's age (78 years old) is the oldest to be reported so far. ${ }^{[6,12]}$ In general, patients older than 50 years old are considered more prone to CAC of the salivary glands with no sex predilection. ${ }^{[3]}$

Salivary gland CAC presents a characteristic histological pattern, composed of multiple cystic structures of variable shape and size, many of which 
exhibiting papillary endocystic projections (justifying the use of the term "papillary CAC"). ${ }^{[3-5]}$ The epithelial lining of CAC consists of small cuboidal, large cuboidal and columnar cells; occasionally other cells types, such as mucous, oncocytic and clear may be present..$^{[5]}$ The microscopic appearance of CAC often resembles its benign counterpart, i.e. cystadenoma, from which is discriminated by the invariably present invasive growth of the former; on the other hand, pleomorphism and mitotic activity are uncommon in CAC. ${ }^{[3,4]}$ Other entities to be included in the microscopic differential diagnosis include mucoepidermoid carcinoma (low grade) and acinic cell carcinoma (papillary cystic variant). ${ }^{[5]}$ In the case presented here, the aforementioned salient histologic features of CAC were observed, including the prerequisite infiltrative growth into surrounding tissues. Noticeable was the relative abundance of mucous cells in the epithelial lining of the cystic spaces.

CAC is regarded as malignancy of low grade, although high-grade variants have occasionally been reported..$^{[4,11,15,16]}$ Pollett et al. ${ }^{[11]}$ described a case of papillary CAC of the tongue, which showed highgrade histologic features (including necrosis, nuclear pleomorphism, and high mitotic activity), accompanied by a clinically aggressive behavior (including lymph node metastasis and local and regional recurrence 6 months after treatment). In addition, one of the aforementioned few published cases of CAC of the sublingual gland was characterized as high grade, on the basis of columnar cell predominance, high cellularity and numerous mitotic figures, as well as the development of recurrence and metastatic spread. ${ }^{[15]}$ In a series 40 patients with available information, only 3 developed recurrences and only 4 showed evidence of loco-regional metastasis. ${ }^{[4]}$ Although no association between histologic type and recurrence was noticed, it was observed that predominance of columnar cells was more common among metastatic cases, including 3 out of 4 labial cases with more than $75 \%$ columnar cells. ${ }^{[4]}$

Treatment of choice of CAC is surgical resection. When neck lymph nodes are involved, a neck dissection should be performed. ${ }^{[16]}$ It has been estimated that regional lymph node metastases are uncommon, present in less than $10 \%$ of CAC cases at the time of diagnosis; late lymph node metastasis is even rarer. ${ }^{[4]}$ Adjunctive radiotherapy is advocated by some authors, especially in cases of high-grade or inoperable recurrent tumors. Nevertheless, the evidence is limited, and the benefit from radiotherapy remains controversial. ${ }^{[11]}$ In the present case, no recurrent or metastatic behavior was observed 18 months after surgical treatment.
In conclusion, a rare case of CAC of the sublingual gland is presented, which constitutes only the sixth documented case and the only one to affect an older female. Awareness of this rare occurrence along with familiarity with the challenges of the histopathologic diagnosis allows correct detection and reporting of similar cases in the future.

\section{Authors' contributions}

Manuscript's preparation: P. Paschalidi

Manuscript's review: N. Nikitakis

Concept design: G. Kostakis

Literature search: D. Igoumenakis

\section{Acknowledgments}

We thank Dr. Jon Wagner for his contribution in language editing.

\section{Financial support and sponsorship}

None.

\section{Conflicts of interest}

There are no conflicts of interest.

\section{Patient consent}

Patient consent was obtained from the patient.

\section{Ethics approval}

The procedures followed were in accordance with the Helsinki Declaration.

\section{REFERENCES}

1. Nishigima W, Tokita N, Takooda S, Tsuchiya S, Watanabe I. Adenocarcinoma of the sublingual gland: case report and 50 year review of the literature. Laryngoscope 1984;94:96-101.

2. Seifert G, Brocherious C, Cardesa A, Evenson JW. WHO international classification of tumors-tentative histological classification of salivary gland tumors. Pathol Res Pract 1990;186:555-81.

3. Brooks HW, Hiebert AE, Pullman NK, Stofer BE. Papillary cystadenoma of the palate: a review of the literature and report of two new cases. Oral Surg Oral Med Oral Pathol 1956;9:1047-50.

4. Foss RD, Ellis GL, Auclair PL. Salivary gland cystadenocarcinomas. A clinicopathologic study of 57 cases. Am J Surg Pathol 1996;20:1440-7.

5. Evenson JW, Cawson RA. Salivary gland tumours. A review of 2410 cases with particular reference to histological types, site, age and sex distribution. J Pathol 1985;146:51-8.

6. Kobayashi I, Kiyoshima T, Ozeki S, Shima K, Shigemura N, Matsuo $\mathrm{K}$, Sakai H. Immunohistochemical and ultrastructural study of a papillary cystadenocarcinoma arising from the sublingual gland. $J$ Oral Pathol Med 1999;28:282-6.

7. Rinaldo A, Shaha AR, Pellitteri PK. Management of malignant sublingual salivary gland tumors. Oral Oncol 2004;40:2-5.

8. Perez DE, Pires FR, Alves F de A, Almeida OP, Kowalski LP. Sublingual salivary gland tumors: clinicopathologic study of six cases. Oral Surg Oral Pathol Oral Radiol Endod 2005;100:449-53.

9. Danford M, Eveson JW, Flood TR. Papillary cystadenocarcinoma of the sublingual gland presenting as a ranula. $\mathrm{Br} J$ Oral Maxillofac 
Surg 1992;30:270-2.

10. Koç M, Yanılmaz M, Yıldırım H, Gök U, Çobanoğlu B. MRI findings of papillary cystadenocarcinoma of the submandibular gland. Diagn Interv Radiol 2010;16:20-3.

11. Pollett A, Perez-Ordonez B, Jordan RC, Davidson MJ. Highgrade papillary cystadenocarcinoma of the tongue. Histopathology 1997;31:185-8.

12. Sun G, Yang X, Tang E, Wen J, Lu M, Hu Q. The treatment of sublingual gland tumors. Int J Oral Maxillofac Surg 2010;39:863-8.

13. Yamazaki T, Kotani A, Kawakami T. Basal cell adenoma of the sublingual gland. J Oral Maxillofac Surg 1987;45:270-3.

14. Yu T, Gao QH, Wang XY, Wen YM, Li LJ. Malignant sublingual gland tumors: a retrospective clinicopathologic study of 28 cases. Oncology 2007;72:39-44.

15. Yamada S, Matsuo T, Baba N, Rokutanda S, Kawasaki G, Mizuno A, Fujita S. High-grade papillary cystadenocarcinoma of the sublingual gland: a case report. J Oral Maxillofac Surg 2007;65:1223-7.

16. Tomioka H, Harada H, Okada N, Omura K. Papillary cystadenocarcinoma arising in the floor of the mouth: report of a case. J Oral Maxillofac Surg 2006;64:864-7. 